Acta Poloniae Historica

106, 2012

PL ISSN 0001-6892

Doubravka Olšáková

\title{
FROM LEGACY AND TRADITION TO LIEUX DE MÉMOIRE*
}

\section{I}

Pierre Nora's concept of realms (rendered by other authors also as 'sites') of memory attracted the attention of Czechoslovak historians already in early 1990s, soon after the publication of his phenomenal work Les lieux de mémoire. ${ }^{1}$ The idea of creating a work in a similar vein appears among Czech historians with remarkable regularity but inevitably meets with serious obstacles, the most serious of which seems to be - somewhat paradoxically - the history of the Czech state and nation itself. Realms of memory of the Czech state often coincide with realms of memory of the Habsburg monarchy, and are in fact mutually inseparable. Their interpretation, however, often radically differs from the way they are understood in Vienna, Budapest, Bratislava, and even Cracow. To paraphrase the title of the Visegrad Fund Conference which took place in December 2011 in Prague, we would perhaps have to agree that in this space, our enemy is all too often our enemy's hero. And thus the notion of shared realms of memory, i.e., lieux de mémoire partagés, ${ }^{2}$ proposed by some West European

* The publication of this article was enabled by the research grant GPP410/11/ P007 funded by the Czech Science Foundation.

${ }^{1}$ A wide range of books on the topic of transformation of historical and collective memory, including the institutional frame, came out in previous years; cf., e.g., Helmut Altrichter (ed.), GegenErinnerung: Geschichte als politisches Argument im Transformationsprozess Ost-, Ostmittel- und Südosteuropas (Munich, 2006); Sorin Antohi, Balázs Trencsényi and Péter Apor (eds.), Narratives Unbound: Historical Studies in Post-communist Eastern Europe (Budapest, 2007); etc.

2 Étienne François, 'Lieux de mémoire, Erinnerungsorte', in Antoine Marès (ed.), Lieux de mémoire en Europe centrale (Paris, 2009), 17. 
historians, is among Czech historians perhaps due to a strong and traditional orientation on nationally Czech history, still relatively little used or known. ${ }^{3}$

II

A VIEW FROM INSIDE

The new situation which arose in Central Europe after communist regimes came to power in the late 1940s, demanded among other things also a new concept of national history. A whole generation of historians was faced with an uneasy task of establishing an interpretation of national history that would suit the new political situation, satisfy the ruling party's ideology, and meet the impoverished populations' deeply felt need to know who were the heroes and who were the villains. This was no mean task and in many cases, substantial amount of intellectual acrobatics was needed to produce the desired effect.

In a number of cases, the new canon of national history in Central Europe was based on, and inspired by, the nineteenth-century Romanticist approach to history. In Bohemia and Moravia, interpretation of Czech history was for a long time based on the notions presented in Zdeněk Nejedlý's popularising work Komunisté, dědici velikých tradic českého národa [Communists, heirs to the great traditions of the Czech nation], ${ }^{4}$ first presented by the author in 1946 as a lecture.

This study became a basic starting point of Czech - and, after all, also Slovak - historiography for decades to come. In a traditional manner, it laid foundations to a new pantheon of Czech history, outlining its progressive achievements (Hussitism, national revival) as well as reactionary elements (Czech aristocrats in the Battle of Lipany, the period of so-called 'darkness', the First Republic). What is somewhat less obvious is that this book also started an important phenomenon that still has a large impact on historiography dealing with the sites of memory in Czech culture. The magic formula was the word 'tradition', in particular 'progressive tradition', which the new regime invoked and relied on, while condemning reactionary elements

${ }^{3}$ An attempt to bridge the aspects of traditional Czech approach is a series of articles on Odsunuté pomníky [Transferred monuments] running by Zdeněk Hojda in the journal Dějiny a současnost since January 2011.

${ }^{4}$ Zdeněk Nejedlý, Komunisté, dědici velikých tradic českého národa (Prague, 1946). 
of Czech history and permitting only a negative interpretation of those historical periods.

This simplifying interpretation of tradition in accordance with Marxist doctrine survived, with little opposition, for a long time. It was only in 1968 that František Graus voiced a strong disagreement with it. He rejected the basic tenet of the 1950s, namely that we adopt only the 'progressive' elements from history, and simply claimed that from history we inherit everything. ${ }^{5}$ Not surprisingly, Václav Král, a historian who became infamous for the almost Stalinist methods he used in enforcing the new interpretation of Czech history, sharply attacked this deviation from a monolithic understanding of history. Unfortunately, thanks to a period of 'normalisation' that engulfed Czechoslovakia after 1968 and in the course of the 1970s affected all the strata of the society, Král won this argument from the position of a dominant Stalinist in power. ${ }^{6}$ What happened, namely, was that František Graus emigrated. Somewhat later, it was Jiří Kořalka who resumed Graus and the issue he put forth in his lecture on the 'Czech question'.7

Thanks to Graus, the notion of traditions (in plural) became a focal point of interest to researchers who actively participated in Hussitologist symposia organised by the Museum of Hussite Revolutionary Movement in the city of Tábor. At the beginning of the period of 'normalisation', this town, outside the circle of central Prague institutions, offered something of a refuge to Jiří Kořalka and František Šmahel, two historians who had to leave the Institute of History of the Czechoslovak Academy of Sciences due to political purges.

Kořalka and Šmahel departed from the notion of 'progressive traditions' of the Czech nation, which was based on Zdeněk Nejedlý's work, by following also traditions other than 'progressive'. In the 1970s, this led to the establishment of the notion of 'second life' which focused on changes in the perception, reflection, and reception of certain nineteenth- and twentieth-century historical phenomena, analysing them as part of processes that shape collective and historical consciousness.

${ }^{5}$ Cf. František Graus, 'Současná krize našeho historického vědomí', Československý časopis historický, xvi, 4 (1968), 488. Cf. idem (ed.), Naše živá i mrtvá minulost -8 esejí o českých dējinách (Prague, 1968).

${ }^{6}$ Václav Král, Myšlenkový svět historie (Prague, 1974).

${ }^{7}$ Ibidem, 196-7. See also Jiří Kořalka, Co je národ? (Prague, 1969). 
This shift originated in discussions about the legacy and tradition of Czech history that went on in the 1960s, but also at the symposia on Hussitism in Tábor, whose scope was broader. They encompassed medieval history, under the auspices of František Šmahel, as well as modern history, under Jiří Kořalka's supervision. These meetings took place in Tábor since $1978 .^{8}$ In retrospect, one could say that they helped form an important generation of Czech historians who knew how to work based not only on the official direction of Czech historiography but also based on perception and transformation of notions this official historiography overlooked. The concept of 'second life' (das Nachleben) was thus born outside the scope of supervision by authorities, at the periphery, in Tábor.

Among the participants of these meetings we find the names of Petr Čornej, Jiří Rak, Ivana Čornejová, Blanka Zilynská, Michal Svatoš, and others. After 1989, historians whose views were formed there went on to publish their pioneering works on reception and reflection of history, which were among the first of this kind in the Czech territory and appeared with H\&H Publishers. While Petr Čornej in his Lipanské ozverny [The echoes of Lipany] analysed the reception of all streams of Hussitism in twentieth-century Czech society, ${ }^{9}$ Jiří Rak in his study Bývali Čechové [There used to be Czechs] focused on the reception of older history in nineteenth-century Czech society. ${ }^{10}$

Another important group was also formed in a close connection with a series of conferences that took place outside Prague, namely the so-called 'Pilsen symposia', held as part of the 'Smetana Days'. ${ }^{11}$ Much like in Tábor, here too, medievalists joined forces with modern historians, and this resulted in important meetings of musicologists, art historians, and historians of modern and contemporary history. These interdisciplinary conferences in Pilsen opened numerous issues that are relevant and studied even today. Among the initiators of these meetings were, e.g., the musicologists Marie Ottlová and Milan Pospíšil and art historians Tomáš Vlček and Roman Prahl. A number of other important scholars such as Zdeněk Hojda, Tatána Petrasová,

\footnotetext{
${ }^{8}$ Specifically, the symposia organised in 1978, 1980 and 1983.

${ }^{9}$ Petr Čornej, Lipanské ozvěny (Jinočany, 1995).

10 Jiří Rak, Bývali Čechové... - České historické mýty a stereotypy (Jinočany, 1994).

11 Cf. <http://www.plzensympozium.cz> [Accessed 19 Feb. 2012].
} 
Markéta Theinhardt, and Jiří Pešek also started their career at the Pilsen meetings.

The two circles soon started overlapping. Before long, one finds among the participants of Pilsen conferences also historians who attended the Tábor meetings. For example, Zdeněk Hojda and Jiří Pokorný, who took part in both symposia, co-authored Pomniky a zapomniky [Memoirs and forgetting], ${ }^{12}$ which mapped the culture of 'memorials' in the sense of 'battlefield of memories' of particular epochs. This book, still relevant today, has been hopelessly sold out.

Both platforms, Hussitological conferences and the Pilsen meetings, played an important role in Czech historiography by forming and shaping a distinct line of thought, which - with the aid of an intentional disinterpretation of a Marxist notion of tradition - created space for free, unfettered research. The notion of description and interpretation of historical phenomena in historical and social consciousness was first formulated in the late 1970s and went on to grow deep roots in the area in question. In fact, it became one of the most important directions in Czech historiography of the second half of the twentieth century.

A new generation of historians who follow in the footsteps of their teachers whose academic career started at Hussitologist congresses seems to have adopted from their teachers something that is rather characteristic for the generation of historians whose most productive years coincided with the time of strictest 'normalisation': a dislike of theories and official methodologies. None of the abovementioned works adopted a clear methodological approach, none aimed at being part of a broader European context of theorising about memory. This can be seen also in Petr Šámal's 2009 publication Soustružníci lidských duší - Lidové knihovny a jejich cenzura na počátku padesátých let 20. století (s edicí seznamů zakázaných knih) [Lathing the human soul: people's libraries and their censorship in the early 1950s (with an edition of the list of banned books)]. ${ }^{13}$ In this study, Sámal departs from the dominant interpretative direction of monolithic indoctrination of the masses in the 1950s, and searches instead for new explanations of how it was possible that in the 1950s, the Czech society adopted the new culture so easily. He focuses on libraries as 'symbolic

${ }^{12}$ Zdeněk Hojda and Jiří Pokorný, Pomníky a zapomníky (Prague, 1996).

${ }^{13}$ Petr Šámal, Soustružníci lidských duší. Lidové knihovny a jejich cenzura na počátku padesátých let 20. století (s edicí seznamů zakázaných knih) (Prague, 2009). 
centres of cultural memory' ${ }^{14}$ and analyses its transformation against the background of censorship-enforced removal of 'the hostile, faulty, obsolete and undesirable literature' from people's libraries.

The most important shift that occurred in the following generation is an inversion of perspective, whereby attention turns away from the study of changes in perception of a historical event, person, or phenomenon, and focuses on uncovering the mechanisms that formed this memory. A question thus offers itself: Did the group of historians sometimes ironically referred to as 'the generation of Hussite Tábor' (in Czech, 'Tábor' means 'camp') manage to transmit to the generation incoming after 1989 their own historical experience - though by then it had already departed from the original notion of 'tradition' or 'second life' inclined towards issues of power-driven changes in the structure of collective memory? It is too early to give a definite answer, but if we take the example of Petr Šámal, we can conclude that he refers not only to the legacy of Petr Čornej but also to Jiří Pokorný ${ }^{15}$ and other members of the circle formed around the Tábor conferences. ${ }^{16}$

Another individual who worked closely with the notion of 'second life' was the late Vladimír Macura, former director of the Institute for Czech Literature, Academy of Sciences of the Czech Republic. His interest in transformation of historical - and in his case, mainly literary - semiotics is perhaps closest to the methodological characterisation of 'realms of memory' as defined in Pierre Nora's work. Instead, however, of relying on the historical, somewhat vague delineation of 'realms of memory', Macura uses a methodologically and thematically precise analysis of semantic fields. His study of the language of national revival, ${ }^{17}$ which reflects all the main interpretative directions of the 1980s, is now considered a classical work on the history of Czech national revival. ${ }^{18}$ Also of seminal importance is his

14 Ibidem, 136.

15 Ibidem, 135.

${ }^{16} \mathrm{Cf}$. the book published at the occasion of the 60th anniversary of Petr Cornej, which brought together historians of the Middle Ages and those dealing with modern and contemporary history: Robert Novotný and Petr Šámal (eds.), Zrození mýtu: dva životy husitské epochy (Prague and Litomyšl, 2011).

17 Vladimír Macura, Znamení zrodu - české národní obrození jako kulturní typ (Jinočany, 1995). A sequel of this publication is idem, Český sen (Prague, 1998).

${ }^{18}$ From the Czech-Polish perspective, works of Maria Janion probably best correspond with the approach of Vladimír Macura. 
book Štastný věk (a jiné studie o socialistické kultuře) [A happy age (and other studies on socialist culture)] on the language and semantics of the communist regime. Macura analyses semantic fields constituted during the communist era, taking into account the fields such as 'paradise', 'death of a leader', 'Colorado potato beetle', 'last battle', and the like.

In his work, Macura reflects upon the close link between the thinking of Czech society in the nineteenth and twentieth centuries. A dominant influence of nineteenth-century notions on the formation and shape of thinking in modern Czechoslovak society was, as observed above, bolstered after the communist takeover in 1948 by a conscious adoption and further transformation of numerous nationalist/Romanticist clichés, which in their diction and emphasis on masses and Czech nation fully corresponded to power interest of the new communist government. ${ }^{19}$ Topics closely linked with, or derived from, the key phenomena of the nineteenth century therefore still represent a fertile soil for an analysis of 'realms of memory'. Very well executed is, for example, the analysis of the position of one of the best-known and most poetic Czech book for children, Broučci [Little Beetles], in the national literature..$^{20}$ Věra Brožová, a nineteenth-century literature historian, analyses the book as such, the circumstances in which it was written, etc., but at the same time, she de-emphasises a classical literary analysis of the text and focuses rather on changes in the perception of this work in three fundamentally different regimes: during the Habsburg monarchy, when it was promoted mainly by a circle of Masaryk's supporters, its position and role in interwar Czechoslovakia, and finally after WWII. She describes how in the late 1950s, there was an unsuccessful attempt to incorporate this fundamentally Protestant fairytale into the pantheon of new communist traditions, and in the 1970s, the book played an important role in the unofficial culture and among the dissidents. In tracing the various transformations in the perception of a children's book that became an icon in the Czech society, and in following the changes its characters have undergone, this study is one of the most successful attempts to bring to life the notion of 'second life', which after a wave of publications in 1994-8, receded after 2000 somewhat into

${ }^{19}$ Cf. the above mentioned publication Nejedlý, Komunisté.

20 Věra Brožová, Karafiátovi Broučci v české kultuře (Prague, 2011). 
the background. Vera Brožová, too, belongs to the circle of scholars whose work has been shaped by the Pilsen meetings.

Alongside these two very influential groups, there have been other attempts at dealing with the concept of 'realms of memory'. Those that try to define the research subject and ground it firmly in the relevant research field tend to be most successful. Less impressive are studies that mechanically adopt notions which disregard the uniqueness of the semantic field of a certain feature in favour of a positivist description, ${ }^{21}$ or drown the concepts in methodologically shallow and vague discourses. ${ }^{22}$

In the development of the notion of 'second life', Vít Vlnas occupies a special place. His publication Jan Nepomucký - česká legenda [John of Nepomuk - a Czech legend] is, in fact, one of the standard works on 'second life'. ${ }^{23}$ And yet, the book appeared in 1993 when Vít Vlnas was just above thirty years old, which made him one of the youngest scholars to approach the notion of 'second life' after 1989. Still, the book clearly follows on the debate that was opened by František Graus in 1968, as witnessed by the following statement Vlnas makes in the closing part of the study: 'The legend of St John [of Nepomuk] is part of the past. But is it really dead? It is not, because history can never be dead' ${ }^{24}$

With the notable exception of Vít Vlnas, most historians who published in the first half of the 1990s on 'second life' were of the generation born in the 1950s. In the second half of the 1990s, the number of works on 'second life' declined and interest in the subject-matter somewhat waned. A new wave of interest came only after 2000. The first decade of the new millennium saw the publication of, e.g., the studies of Jan Galandauer, ${ }^{25}$ who tends to use the notion

${ }^{21}$ Cf., e.g., Luboš Velek, 'Toaletní papír a jeho politická symbolika - Královský reskript z roku 1871', Dějiny a současnost, xxviii, 8 (2006), 12. The article is an abridged version of idem, 'České státní právo na toaletním papíre. Mýtus, skutečnost a jejich symbolický význam. Př́spěvek k počátkům české moderní politické kultury a jejího dědictví', in Milan Řepa (ed.), 19. století v nás. Modely, instituce a reprezentace, které pretrvaly (Prague, 2008), 301-27.

22 Jan Randák, 'Symbolické osmičky - Role českých osmiček a jejich demokratický př́iběh', Dějiny a současnost, xxx, 8 (2008), 14-17.

${ }^{23}$ Vít Vlnas, Jan Nepomucký - česká legenda (Prague, 1993).

${ }^{24}$ Ibidem, 258-60.

${ }^{25}$ See Jan Galandauer, 2.7.1917 - bitva u Zborova: česká legenda (Prague, 2002) and idem, 6.7.1915 - pomník Mistra Jana Husa: český symbol ze žuly a bronzu (Prague, 2008). 
of 'invented tradition' in the sense proposed by Eric Hobsbawm. According to this British historian, invented traditions have three basic functions: (i) to establish social cohesion within a society or its groups; (ii) to legitimise or provide grounding to institutions, statuses, and authority; (iii) to serve as a socialising factor that helps form a uniform system of values, behaviour patterns, etc. ${ }^{26}$ This profile is well-suited for the Czech academic milieu, which has been rather averse to excessive theorising. On the one hand, one finds here an emphasis on the function of official historiography, i.e., the state, but on the other hand, it also highlights the divergence between the state and social thought, that is, collective memory, which does not follow the goals of the state but rather aims at preserving internal cohesion one's own group, which is, in our case, the nation.

A memorial act includes an integrating element that appeals to emotions, aims at creating an identity, creating a cohesive group united by a constructed, emotional image of the past. This image, however, aims into the future: participants of memorial ceremonies are urged to fulfil a legacy, commemorations recall the heroism of the fallen and exhort subsequent generations to follow in their footsteps. ${ }^{27}$

Memory - and its function in society - is viewed in a similarly constructivist manner:

Memory represents the presence of the past, its psychological and intellectual reconstruction, which is supposed to ensure the continuity of time and defy continuous change; it is a basic element of identity. ${ }^{28}$

These works are grounded in the classical concept of 'second life' but Galandauer in his work also attempts purely theoretical reflections, though these remain in a rather fragmentary state. The approach used in analysing the transformation of perceptions of the Battle of Zborov (1917), this almost mythical birth of the Czech military resistance against Austria during WWI, is also found in Galandauer's other work - in his study of the fortunes of one of the best known Czech national

${ }^{26}$ Eric Hobsbawm and Terence Ranger (eds.), The Invention of Tradition (Cambridge, 1983), 13. Among works inspired by Hobsbawm's approach, cf., e.g., John R. Gillis (ed.), Commemorations: The Politics of National Identity (Princeton, 1994).

${ }^{27}$ Galandauer, 2.7.1917, 99.

${ }^{28}$ Ibidem. 
monuments: the memorial of Jan Hus at the Old Town Square in Prague. It turns out that the actual story of this national symbol is so very banal that the aura which surrounds it clearly must have originated in a notional construct linked to the image of Hussitism and the legacy of the first President because - as far as the facts are concerned nothing very important has ever happened at this important memorial. Even Masaryk, during his presidency, was somewhat inclined to avoid such opportunities.

Perhaps the most thorough attempt at grasping the concept of 'second life' is found in the Eduard Maur's book Pamét hor [Memory of the mountains].$^{29}$ Mountains have been an important notion to the Czechs since time immemorial. After all, in the past, mountain ranges on the borders seemed to be the most important defence against Germanic invasions. Maur analyses them both in the context of environmental history (relying on the work of biologist and sociologist Hana Librováa ${ }^{30}$ ), and in social/political and cultural/historical context. And though this study remains firmly grounded in the Czech tradition of conceptualising and contextualising the memory of places, ${ }^{31}$ in the closing part of the book, Maur places his conclusions in a European context:

As in many realms of memory in Europe but even outside it, the memory of our mountains is often connected with war, mostly victorious, sometimes real, other times completely fictional. ${ }^{32}$

Another feature that makes this work particularly important is that this is one of the first attempts made in the Czech milieu to open the issue of exhaustion of traditional patterns of forming collective memory; patterns that in a multinational and multicultural Europe do not correspond to national interests, as they were promoted in the nineteenth century. ${ }^{33}$ This issue - the fading, depletion or exhaustion of traditional patterns that form the historical memory of a nation

${ }^{29}$ Eduard Maur, Pamět hor (Šumava, Říp, Blaník, Hostýn, Radhošt') (Prague, 2006).

${ }^{30}$ See, e.g., Hana Librová, Sociální potřeba a hodnota krajiny (Brno, 1987); eadem, Láska ke krajině? (Brno, 1988).

31 Maur, Pamět' hor, 19-21.

32 Ibidem, 344.

33 Ibidem, 351. 
- had not been much discussed in the Czech territory in the past but lately, it is finding more resonance and reception.

Alongside historians and historians of literature, one should in this context also pay due attention to sociological analyses of the functions of particular state holidays and anniversaries. Although they refer neither to the traditional - and in the historical community very popular - notion of lieux de mémoire, nor to the indigenous Czech tradition of 'second life', they do analyse the formation of historical consciousness from the perspective of sociology of memory. One of the foremost sociologists who tried to adapt this notion to the Czech environment is Jan Keller, whose role in Bohemia could be, as far as his influence and stature is concerned, compared in international context perhaps only to that of Slavoj Žižek. Albeit in the Czech Republic he is usually perceived mainly through the prism of his open sympathies with the Left - which lent him a certain aura of exoticism in Czechoslovak anti-communist circles - a closer look reveals that he is firmly grounded in traditional French sociology of bureaucracy and state administration. And this link, together with sociology of memory, makes his texts an interesting, important, and in the Czech historical community somewhat unjustly undervalued phenomenon. His analysis of exhaustion of the content of state holidays, their loss of ability to shape and form a nation or a tribe as they did in the past, is based on a synthesis of the work of Roger Caillois (1913-78), the French anthropologist and philosopher, and the writings of the American sociologist Hugh Dalziel Duncan. What Keller sees as happening is a shift from a collective remembrance of the past, such that was exemplified by massive celebrations of anniversaries and state holidays, towards a collective withdrawal into the privacy of one's own homes, where celebrations can be followed, thanks to mass media, in a mediated fashion.

His analysis is supported by sociological arguments but it also offers a very accurate generalisation of the historical importance of all these collective celebrations:

Despite all this, festive commemorations happen in all sorts of countries and relate to all sorts of dates following one, time-tried pattern. Collective recollection of the past that usually is their part is neither a nostalgic remembrance nor a seriously meant historical analysis. This regular, periodic remembering is a response to the need of a reliably and quite clearly ordered past, which exists in every society. Unambiguously and comprehensibly 
ordered past strengthens people's trust in the present by documenting a continuity of values promoted by a particular regime. If we explain the past from the perspective of currently proclaimed values, everyone can find out - with satisfaction and a sense of relief - that from the very outset, the issues at stake have been exactly the ones he or she cares about. ${ }^{34}$

On the other hand, as mentioned above, the arrival of globalisation and of new ways of communication that accompany it - direct television broadcast, internet, etc. - leads to a deflation, an emptying of this 'state-building' aspect of holidays. Instead of confirming and supporting a social/national/state-endorsed hierarchy of values that are proclaimed publicly and with the blessing of the highest authorities, it offers an escape into the private sphere:

At the occasion of a state holiday, each one of us gets a sort of little present. We are released into our privacy and for the duration of a full day or even longer, we can live far from the state authorities, state schools, and state companies. There is altogether nothing reasonable about it but it is nice. ${ }^{35}$

What links the group of scholars that formed around the 'Hussite Tábor' (and their students), literary historians, and sociologists who deal in their research with the social importance of state holidays, is the perception of a close connection between the mechanism of state power and the formation of collective memory. This is also perhaps where they most differ from the classical concept introduced by Pierre Nora, who in many ways puts more emphasis on the national context rather than state setting. In totalitarian regimes, however, the state and its power mechanisms determine the formation of memory according to pre-set ideological patterns. Their role is thus crucial and determining.

In this context, it is hard to escape the impression that though from a different angle, the new research of formation of collective memory is also the subject of the French historian Françoise Mayer's study Češi a jejich komunismus. Pamět' a politická identita [Czechs and their communism: memory and political identity]. ${ }^{36}$ Here, the author analyses how the communist past was perceived by the Czechoslovak society after 1989. She describes mechanisms that formed some

${ }^{34}$ Jan Keller, Nedomyšlená společnost (4th edn Brno, 2003), 79.

${ }^{35}$ Ibidem, 87.

${ }^{36}$ Françoise Mayer, Češi a jejich komunismus. Pamět a politická identita, trans. Helena Beguivinová (Prague, 2009). 
modern myths Czechs are proud of, such as the maintenance of constitutional continuity and continuity of the socialist ideal in the course of the entire Czechoslovak twentieth century. Françoise Mayer focuses mainly on the price which historical memory pays for the formation and ongoing confirmation of continuity, this most fragile part of the construction of the new Czech national identity. The emphasis on describing the relation between the state and memory, which Mayer approaches from the perspective of 'laws of memory', shifts this work away from the classical concept of historical analysis and towards an analysis of social aspects of lawmaking. This seemingly somewhat obscure subject can be, however, presented with a large amount of ingenuity, as seen for example in Jiři Přibáň's work. This author deals with the social impact of legislation in a broader framework, but emphasis on social context is very much present.

The abovementioned study was not Françoise Mayer's first publication on this issue. Already in 2008, she published, in collaboration with Zdeněk Vašíček, a study Minulost a současnost, pamět a dějiny [The past and the present, memory and history]. ${ }^{37}$ The focus there was on the role and function of the state in forming a 'story of history', in shaping a great narrative about the great past, which is presented as heroic and a taboo by those who want it to conform to their needs. In the French scholarship, Sophie Couré opened a somewhat related subject, namely investigation of the role and function of archives. ${ }^{38}$ Archives as war booty, a hitherto somewhat neglected topic, predetermine, in a way, the possibility of creating a canon of national history that would suit the new regime. By controlling archives - its own and those of others - a regime gains crucial control over possibilities of alternative interpretations.

French influence probably played a dominant role in interpreting 'second life' and traditions, despite much delayed reception of primary literature of this subject: only in 2009, eighty-four years after its publication, a translation of Maurice Halbwachs's work Mémoire collective appeared, for the first time ever, in the Czech Republic. ${ }^{39}$

37 Zdeněk Vašíček and Françoise Mayer, Minulost a současnost, pamět’ a dějiny (Brno, 2008).

38 Sophie Cœuré, La mémoire spoliée. Les archives des Français, butin de guerre nazi puis soviétique (de 1940 à nos jours) (Paris, 2007).

${ }^{39}$ Maurice Halbwachs, Kolektivní pamět' (Prague, 2009). 
One should, however, pay attention also to a work where research of memory is used to investigate social reality or to analyse the legitimising function of memory in a political context. In his study Pamét a genocida. Úvahy o politice holocaustu [Memory and genocide: reflections on the politics of Holocaust], Pavel Barša presents a concise analysis of polemics and debates relating to American and European reflections on the Nazi genocide of Jews. ${ }^{40}$ In the concluding part of the book, Barša divides recollections and interpretations in two basic groups depending on their function: the first works with the image of genocide in order to affirm a certain conception of shared humanity, while the other uses this image mainly in order to secure its own position or to justify its positions by excluding this image. In this sense, it is a classical example of a study on the political function of the politics of forgetting. Barša, however, is one of a few scholars who start their study of the subject with a detailed analysis of the relation between memory, history, and historical awareness (in which he relies mainly on Maurice Halbwachs's work). He also poses an extremely relevant question, one that became even more urgent especially since WWII, and mainly in relation to the Shoah: In investigating history and memory, who should have the last word: a historian or a witness, eventually a direct participant? In the last few decades, the shift in the relation between history and memory became an important milestone. It is for a good reason that especially due to the influence of the Shoah, the French historian Annette Wieviorka calls the twentieth century Ère du témoin, that is, 'the Era of Witnesses'. ${ }^{41}$ This notion, which Czech historians find as difficult to tackle as they once did when dealing with oral history, seems, however, particularly well suited to mapping events still socially and historically taboo, such as expulsions, ethnic and political purges, etc.

Interviews with witnesses (survivors) have not only a descriptive function and are not just about collecting items in the sense of capturing as many recollections as possible. On a symbolic level, they also play a therapeutic role - by engaging in such interview, one enters into a dialogue with people who were supposed to be forgotten and expelled from the history of a nation, state, or society. ${ }^{42}$ A dialogue

${ }^{40}$ Pavel Barša, Pamět' a genocida. Úvahy o politice holocaustu (Prague, 2011).

41 Annette Wieviorka, Ėre du témoin (Paris, 2002).

42 This kind of publication is very popular, in particular, within the frame of school educational projects, which result e.g. into books like Ondřej Matějka (ed.), 
between a historian and a witness is an expression of subjectivisation and objectivisation of history, whose distance thus increases and becomes more polarised. The dialogue form demands from a historian much more than the classical methods of current historical craft.

III

\section{A VIEW FROM OUTSIDE}

As one can see in Jan Keller's work, and in other abovementioned publications, inspirations from abroad have arrived in the Czech area in a variety of ways. A closer look reveals a rather surprising realisation that the institutionalised base of various historical commissions and associations plays a prominent role in this process. The current situation testifies to the dominance of two main methodological directions whose influence on Central-European historiography in the past few decades has been in many ways stronger than, for example, the globally dominant, but in Central Europe rather weakened, influence of Anglo-Saxon historiography.

The two abovementioned dominant sources of inspiration are found in the German and French writing on history. Though the main research subjects and methods are reflected by Czech scholars continuously, it is natural that 'official circles' deal with an already established subject only after a certain delay. In the Czech environment, both historical commissions - i.e. the Czech-Slovak-German one and the Czech-Slovak-French one - started treating the subject of realms of memory or 'culture of remembrance' after 2005. The Czech-Slovak-German commission published in 2005 an anthology on Diktatur, Krieg, Vertreibung: Erinnerungskulturen in Tschechien, der Slowakei und Deutschland seit $1945 .{ }^{43}$ In the introduction, the authors speak of some sort of European 'map of memories', which was significantly transformed by the fall of the Iron Curtain in 1989 and after the

Tragická místa paměti. Průvodce po historii jednoho regionu 1938-1945/Tragische Erinnerungsorte. Ein Führer durch die Geschichte einer Region 1938-1945 (Prague, 2010).

${ }^{43}$ Christoph Cornelißen, Roman Holec and Jiří Pešek (eds.), Diktatur - Krieg - Vertreibung: Erinnerungskulturen in Tschechien, der Slowakei und Deutschland seit 1945 (Essen, 2005). In Czech: iidem (eds.), Diktatura - válka - vyhnání: Kultury vzpomináni v českém, slovenském a německém prostředi od roku 1945 (Ústí nad Labem, 2007). 
break-up of the USSR in 1991. They found these notions upon Pierre Nora's 2001/2 study called, rather aptly, 'Gedächtniskonjunktur'. ${ }^{44}$

The book includes Christoph Cornelißen's very well researched study $O$ výzkumu kultury paměti $v$ západni a východni Evropě - metody a otázky [On the research of the culture of memory in Western and in Eastern Europe: methods and questions], which, unfortunately and despite its name, deals almost exclusively with Western Europe. ${ }^{45}$ Other texts treat the culture of memory and remembrance in various aspects. By its choice of subject, namely, the war and expulsion, the commission in fact reflected the mood in the society where this issue had in preceding years been hotly debated, especially prior to Czech Republic's accession to the EU. Even so, this publication as a whole offers one of the most interesting treatments of this topic to date. ${ }^{46}$

Perhaps the most classical attempt to apply the French concept of lieux de mémoire to the Czech environment is the publication Lieux de mémoire en Europe centrale, ${ }^{47}$ which was created by Antoine Marès's initiative. In 2007, the director of the Institut d'Études Slaves proposed that within the framework of activities of the Czech-Slovak-French commission, the subject of realms of memory should also be studied. This resulted in two conferences, one in Paris, one in Prague, and in the abovementioned publication.

In the 'Avant-propos' of this publication, Antoine Marès analyses the main constitutive differences between the creation and perception of 'realms of memory' in France and in Central Europe. He notes that while in France the concepts commonly used in connection with realms of memory are 'identity', 'memory', and 'legacy' (identité, mémoire, patrimoine), in Central Europe, the terms used are closer to the German linguistic perception and scholars here speak of 'con-

${ }^{44}$ See Pierre Nora, 'Gedächtniskonjunktur', Transit, 22 (2001/02), 18-31, available at <http://www.eurozine.com/articles/2002-04-19-nora-de.html> [Accessed 2 Dec. 2011].

${ }^{45}$ Christoph Cornelißen, 'O výskume kultúry pamäti v západnej a východnej Európe. Metódy a otázky', in idem, Holec and Pešek (eds.), Diktatura - válka vyhnání, 23-42.

${ }^{46} \mathrm{~A}$ contribution on the edge of classical historical and political-science analysis is a monograph by Christian Domnitz, Zápas o Benešovy dekrety pred vstupem do Evropské unie. Diskuse v Evropském parlamentu a v Poslanecké sněmovně Parlamentu $\check{C} R v$ letech 2002-2003 (Prague, 2007).

${ }^{47}$ Marès (ed.), Lieux de mémoire. 
sciousness', 'awareness', and 'culture of memory'. ${ }^{48}$ The continuity of French history, where the nation firmly coalesced with the state, is reflected also in a different choice of methods used to approach the phenomenon of realms of memory. And though the concept of French state nation is being revised under pressure from regionalism and the formation of a new identity of immigrant community - who demands recognition of its own historical role in the history of the French state and nation - it seems that despite these shocks, the concept of French identity remains firmly grounded in French consciousness. Antoine Marès is therefore right to point out that terminology is an important feature in forming a relation to the past. In the Czech environment, the word 'identity', or 'Czech identity' is seldom used or found. In France, the opposite is the case.

Both commissions, the official German one and the (officially never fully established) commission of Czech, Slovak, and French historians, produced many more publications than the two mentioned here. In the Czech context, however, it is interesting to try and follow how, separately and yet in a certain concord or likeness of purpose, the work of both commissions reflected the gradual shift of discussions - from realms (sites) of memory and culture of remembrance all the way to national traditions or national tradition.

\section{IV \\ CONCLUSION}

Henry Rousso, the French historian of modern history, writes in one of his works that memory is not what it used to be. Since the 1990s, methodological approaches to working with memory have followed one another in quick sequence but even they cannot be seen in isolation from the environment that formed them. In the Czech environment, reflection on continuity and various interactions that shaped the phenomenon goes back to the 1970s - the time an intentional misinterpretation of the Marxist approach to historiography gave rise to the phenomenon of 'second life'. This concept then influenced a generation of Czech historians, and for many, it is relevant still. It is therefore hopefully not too nationalist to claim - based on previous argumentation - that in the Czech realm, historiographic studies on

${ }^{48}$ Ibidem, 8. 
sites/realms of memory and the related methodology tend to be most comprehensive and most interesting whenever, on the one hand, they actively adopt methodological inspiration from the outside, whilst remaining, on the other, firmly based in Czech historiography and its developments since the 1970s; when they adapt foreign inspirations to the Czech environment, and when they aim, albeit sometimes almost didactically, at absorbing everything that is substantial. Throughout all this, the studies and methodology in question stays true to their own tradition and, after all, to their legacy as well. 